Jurnal Pengabdian Masyarakat Sains Indonesia

\title{
Pendampingan Kelompok Guru IPA Di SMPN 3 Batukeliang dalam Mengembangkan Perangkat Pembelajaran K-13 untuk Melatih Kemampuan Berpikir Kritis Siswa
}

\author{
Ni Nyoman Sri Putu Verawati ${ }^{{ }^{*}}$, Wahyudi ${ }^{1}$, Syahrial Ayub ${ }^{1}$, Satutik Rahayu ${ }^{1}$ \\ ${ }^{\text {I}}$ Program Studi Pendidikan Fisika, FKIP Universitas Mataram, Mataram, Indonesia
}

*Corresponding Author: Ni Nyoman Sri Putu Verawati, FKIP Universitas Mataram, Mataram, Indonesia; Email:veyra@unram.ac.id

\begin{abstract}
Abstrak: Kegiatan pengabdian pada masyarakat ini bertujuan memberikan pelatihan kepada para guru di SMP Negeri 3 Batukeliang dalam mengembangkan perangkat pembelajaran IPA sesuai kurikulum K-13 untuk melatih kemampuan berpikir kritis siswa. Metode yang digunakan untuk mencapai tujuan tersebut, yaitu melakukan serangkaian kegiatan In Service Training (IST) dan On Service Training (OST). Kegiatan In Service Training (IST) dilakukan dengan menggunakan pendekatan andragogis yang mengedepankan metode ceramah, diskusi, dan presentasi. Hasil kegiatan IST telah meningkatkan pemahaman guru tentang konsep pengembangan perangkat pembelajaran IPA berbasis K-13. Selanjutnya, kegiatan On Service Training (OST) dilaksanakan pada saat guru menyusun Perangkat pembelajaran IPA yang bisa diterapkan dalam proses pembelajaran di kelas. Waktu pelaksanaan kegiatan selama 4 (empat) bulan dengan luaran yang dihasilkan, yaitu: a) jasa, berupa meningkatnya kompetensi guru yang terlibat dalam kegiatan pelatihan dalam menyusun perangkat pembelajaran IPA berbasis K-13, b) produk, berupa tersusunnya perangkat pembelajaran IPA berbasis K-13 Perangkat yang dimaksud adalah silabus, Rencana Pelaksanaan Pembelajaran (RPP), serta bahan ajar (buku ajar dan LKS) untuk melatih kemampuan berpikir kritis siswa
\end{abstract}

Kata kunci: Perangkat pembelajaran IPA, kemampuan berpikir kritis

\section{Pendahuluan}

Pemberlakuan K-13 telah memunculkan keresahan di kalangan para guru, karena sesuai dengan amanah yang tertuang dalam Permendikbud Nomor 20 Tahun 2016 tentang SKL Pendidikan Dasar dan Menengah, karakteristik lulusan sekolah menengah yang diharapkan salah satunya adalah memiliki keterampilan berpikir kritis. Sebagai konsekuensinya, guru dituntut untuk melakukan kegiatan pembelajaran dengan pendekatan saintifik yang bertujuan ke arah melatih berpikir kritis, tentu dalam hal ini guru juga harus menyiapkan perangkat pembelajaran berupa silabus, rencana pelaksanaan pembelajaran (RPP), dan bahan ajar berdasarkan pendekatan saintifik yang bertujuan ke arah melatih berpikir kritis itu sendiri, termasuk menyiapkan instrumen tes kemampuan berpikir kritis. Para guru menjelaskan bahwa penyusunan perangkat yang berorientasi kemampuan berpikir kritis masih terasa sulit, karena belum memahami tentang berpikir kritis secara mendalam dan belum mengetahui bagaimana penjabaran indikatorindikator dalam berpikir kritis dalam pembelajaran, apalagi sampai pada penyusunan RPP. Keadaan ini menyebabkan guru sampai dengan saat ini mengajar dengan mengacu pada kurikulum sebelumnya, walaupun label kurikulum yang diterapkan sekolah adalah Kurikulum 2013.

Tim pengusul PMK juga melakukan analisis dan evaluasi bersama dengan guru-guru mata pelajaran Ilmu Pengetahuan Alam (IPA) di sekolah tersebut tentang kesesuaian antara kisi-kisi soal yang telah disusun dengan soal-soal yang telah diujikan. Kegiatan ini dilakukan karena menurut pengakuan para guru, membuat alat evaluasi sesuai kisi-kisi yang diharapkan masih kesulitan apalagi ditambah dengan tuntutan lainnya. Hasil analisis dan evaluasi secara bersama diperoleh bahwa soalsoal yang telah digunakan Untuk mengukur kemampuan kognitif tidak sampai pada kemampuan aplikasi (C3), apalagi sampai analisis (C-4), sedangkan jika ditinjau dari soal-soal ujian 
nasional, soal-soal tingkat SMP disusun untuk mengukur kemampuan kognitif sampai pada tingkat analisis (C4). Lebih jauh para guru mengatakan bahwa peyusunan soal-soal evaluasi sesuai dengan kisi-kisi yang telah disusun sendiri saja masih menjadi problema, apalagi tuntutan untuk melatih kemampuan berpikir kritis.

Secara umum, deskripsi tersebut menunjukkan bahwa pembelajaran tingkat sekolah menengah di Indonesia kurang menekankan ke arah berpikir tingkat tinggi, sehingga begitu dihadapkan pada permasalahan yang membutuhkan keterampilan berpikir tingkat tinggi, siswa sekolah menengah relatif kesulitan. Laporan TIMSS pada tahun 2015 menyatakan bahwa hanya 5\% dari siswa Indonesia yang dapat mengerjakan soal-soal dalam kategori tinggi dan advance, yang memerlukan penalaran (berpikir kritis). Di sisi lain, $78 \%$ siswa Indonesia hanya dapat mengerjakan soal-soal kategori rendah yang memerlukan knowing atau hafalan saja. Sementara Negaranegara Asia seperti Jepang, Korea, Taiwan, Hongkong, Singapura, Malaysia, dan Thailand berada di atas Indonesia (TIMSS, 2015). Selain itu, hasil studi PISA menunjukkan Indonesia menduduki peringkat 69 dari 76 negara, atau peringkat 7 dari bawah. Diketahui juga bahwa siswa Indonesia menguasai pelajaran hanya sampai pada level 3, sementara negara-negara lain ada yang mencapai level 4, 5, dan 6 (PISA, 2015).

Terkait dengan permasalahan ini, berbagai upaya telah dilakukan oleh pimpinan di sekolah tersebut untuk terus berupaya mengembangkan kemampuan para guru dalam penguasaan kurikulum 2013, seperti: (1) mengikutsertakan para guru mata pelajaran Ilmu Pengetahuan Alam (IPA) untuk mengikuti kegiatan pelatihan baik di internal maupun yang diselenggarakan oleh pemerintah Kabupaten atau Provinsi; (2) optimalisasi pelaksanaan kegiatan yang mengarah pada pemahaman kurikulum tahun 2013 melalui Musyawarah Guru Mata Pelajaran (MGMP), dan (3) melakukan kegiatan evaluasi perangkat pembelajaran yang telah disusun dan monitoring proses pelaksanaan pembelajaran di kelas. Walaupun berbagai upaya telah dilakukan, dengan melihat fenomena yang terjadi di lapangan ternyata hasil yang dicapai masih jauh dari harapan. Hal ini disebabkan karena; (1) guru yang dilibatkan dalam kegiatan pelatihan adalah guru yang memiliki status PNS dan sekaligus menjabat Wakasek, sedangkan guru IPA di sekolah tersebut diisi juga oleh guru non PNS dan mereka tidak dilibatkan. (2) Ketersediaan fasilitas pembelajaran yang kurang mendukung, sebagai contoh fasilitas berupa alatalat dan bahan laboratorium pada pembelajaran IPA sangat minim. (3) Sekolah tersebut berada di daerah terpencil dan tergolong desa tertinggal, yang menyebabkan siswa yang ada dalam keadaan ekonomi kurang mampu, tentu hal ini juga mempengaruhi pembelajaran mereka secara tidak langsung.

Berdasarkan analisis situasi di atas, maka sangat penting untuk dilakukan kegiatan PMK dengan tema "Pendampingan Kelompok Guru IPA di SMPN3 Batukliang dalam Mengembangkan Perangkat Pembelajaran K-13 untuk Melatih Kemampuan Berpikir Kritis Siswa." Rencana kegiatan ini sangat didukung oleh sekolah yang dijadikan mitra untuk lebih mempersiapkan diri dalam mengimplementasikan Kurikulum 2013.

Menurut Thompson (2011), dalam membelajarkan kemampuan berpikir kritis membutuhkan pendekatan pembelajaran yang holistik dan harus melibatkan satu set pembelajaran yang tepat dan berorientasi pada tujuan yang memungkinkan peserta didik untuk memanipulasi keterampilan kognitifnya. Kajian tersebut tentu menjadi bagian yang sangat penting yang mendorong tim pengusul merencanakan kegiatan PMK di sekolah mitra yang telah dideskripsikan sebelumnya.

\section{Metode}

Metode pendekatan yang ditawarkan untuk menyelesaikan permasalahan mitra berdasarkan kesepakatan tim PMK dengan mitra, yaitu dengan metode pelatihan dan pendampingan. Pendidikan dan pelatihan (training) dilaksanakan melalui metode In Service Training (IST). IST dilakukan dengan pendekatan andragogis yang mengedepankan metode ceramah, diskusi, dan presentasi, dengan harapan dapat meningkatkan kompetensi kelompok guru mitra. IST dalam kegiatan ini, yaitu meningkatkan kompetensi dalam hal;

1. Analisis pembelajaran dari Kompetensi Inti (KI) dan Kompetensi Dasar (KD) dijabarkan menjadi sejumlah indikator kemampuan berpikir kritis.

2. Konsep perangkat pembelajaran K-13 yang meliputi silabus, RPP, dan bahan ajar (buku ajar dan LKS). 
3. Konsep pengembangan perangkat pembelajaran K-13 yang meliputi silabus, RPP, dan bahan ajar (buku ajar dan LKS) yang dapat melatihkan kemampuan berpikir kritis siswa.

4. Assessmen kemampuan berpikir kritis.

Pendampingan (mentoring) dengan metode

On Service Training (OST), melalui kegiatan workshop guru dalam menyusun perangkat K-13 yang spesifik untuk melatih kemampuan berpikir kritis siswa. OST dilaksanakan secara intensif sampai dihasilkannya dokumen perangkat K-13 yang spesifik untuk melatih kemampuan berpikir kritis siswa. Dalam kegiatan OST, kelompok mitra menghasilkan dokumen perangkat K-13 berupa silabus, Rencana Pelaksanaan Pembelajaran (RPP), serta bahan ajar (buku ajar dan LKS) untuk mata pelajaran IPA.

\section{Hasil dan Pembahasan}

\begin{tabular}{lcrr}
\multicolumn{4}{c}{ Telah dilaksanakan kegiatan pengabdian } \\
kepada & masyarakat & dengan & tema \\
"Pendampingan kelompok & guru IPA di & SMPN3
\end{tabular} Batukeliang dalam mengembangkan perangkat pembelajaran K-13 untuk melatih kemampuan berpikir kritis siswa." Kegiatan pengabdian ini bertujuan untuk meningkatkan pemahaman dan keterampilan guru di SMP Negeri 3 Batukeliang dalam mengembangkan perangkat pembelajaran $\mathrm{K}$ 13 untuk melatih kemampuan berpikir kritis siswaTahap awal kegiatan pengabdian ini, yaitu persiapan. Kegiatan yang dilakukan pada tahapan ini meliputi: menyusun ToR (Term of Reference), identifikasi calon peserta, pertemuan internal tim pengabdian (seperti penentuan waktu pelatihan, tempat, dan materi), dan pengurusan izin melaksanakan kegiatan pengabdian. Peserta kegiatan ini melibatkan guru-guru di SMP Negeri 3 Batukeling Lombok Tengah. Tahap persiapan setidaknya membutuhkan waktu sekitar 1 (satu) bulan, karena di samping persiapan peserta dan administrasi kegiatan, persiapan internal juga dilakukan di mana dalam ToR, Tim kegiatan pengabdian rutin bertemu untuk mendiskusikan materi kegiatan yang nantinya akan disampaikan kepada para peserta kegiatan.

Tahap selanjutnya dilakukan pendidikan dan pelatihan melalui mekanisme In Service Training (IST). Kegiatan yang dilakukan pada tahapan ini, antara lain memberikan pendidikan dan pelatihan kepada guru tentang pengembangan perangkat mata pelajaran IPA yang meliputi: silabus dan RPP, bahan ajar siswa, LKS, lembar penilaian dan demontrasi cara mengajar berbasis saintifik. Kegiatan IST berjalan kurang lebih selama 1 (satu) bulan.

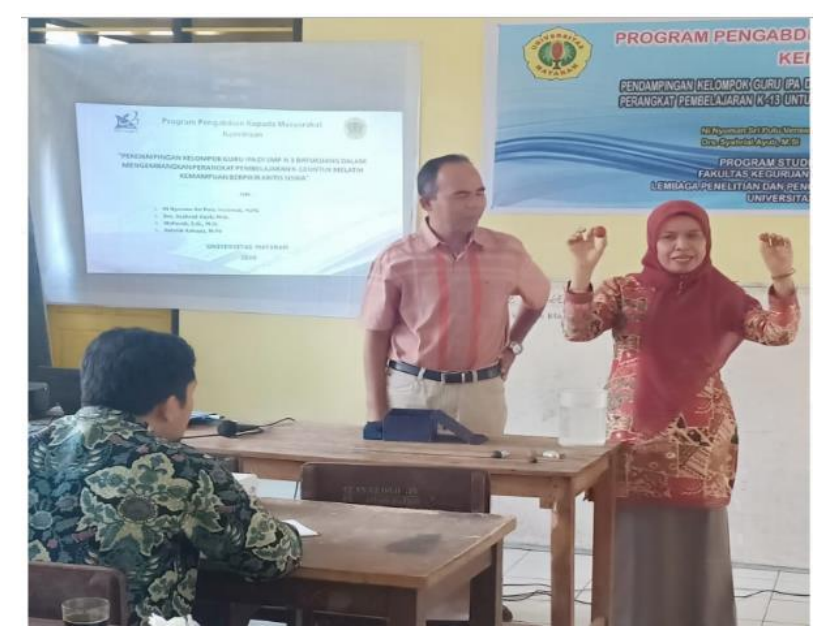

Gambar 1 Pelatihan pengajaran menggunakan pendekatan saintifik

Dalam kegiatan IST ini Tim Pengabdian memberikan pemahaman mendalam terkait hal ini, diskusipun berjalan cukup menarik karena para guru sangat antusias dengan materi dan demontrasi mengajar yang disampaikan. Setelah kegiatan IST, selanjutnya kegiatan berlanjut ke tahap On Service Training (OST). Kegiatan yang dilakukan pada tahapan ini, yaitu memberikan pendampingan kepada guru dalam menyusun perangkat pembelajaran. Sampai dihasilkannya produk, kegiatan OST berjalan selama 1 (satu) bulan. Adapun produk yang dihasilkan, yaitu berupa tersusunnya perangkat pembelajaran IPA yang dihasilkan guru yang terlibat dalam kegiatan pengabdian.

$\begin{array}{rrr}\text { Selanjutnya } & \begin{array}{r}\text { dalam } \\ \text { kegiatan } \\ \text { pengabdian ini dilakukan }\end{array}\end{array}$ evaluasi dan pelaporan. Kegiatan pada tahapan ini dimaksudkan untuk mendeteksi dan mengevaluasi keseluruhan kegiatan pelatihan sehingga dapat diketahui hasil, teridentifikasi permasalahan atau kendala yang muncul, faktor yang mendukung dan menghambat serta solusi pemecahanya. Kegiatan monitoring dan evaluasi dilakukan selama proses kegiatan. Hasil monitoring dan evalusi menunjukkan kegiatan telah berjalan dengan baik sesuai target yang diharapkan. Keseluruhan kegiatan selanjutnya 
dibuat dalam bentuk laporan akhir yang dapat dipertanggung jawabkan kepada pihak-pihak yang terlibat.

\section{Kesimpulan}

Pelaksanaan kegiatan pengabdian kepada masyarakat telah berjalan dengan baik, di mana target luaran berupa jasa dan produk kegiatan telah tercapai. Melalui kegiatan pengabdian kepada masyarakat, para guru di SMP Negeri 3 Batukeliang telah memiliki kompetensi dalam mengembangkan perangkat pembelajaran IPA dan dapat mengaplikasikannya dalam proses pembelajaran.

\section{Saran}

Perlu dilakukan kegiatan serupa untuk dilaksanakan di sekolah-sekolah kawasan terpinggirkan, karena kita tahu persis keterbatasan akses telah berakibat pada kurangnya kompetensi guru dalam pemahaman pengembangan perangkat pembelajaran IPA berbasis K-13 untuk meningkatkan kemapuan berpikir kritis siswa.

\section{Ucapan Terima Kasih}

Penulis mengucapkan terima kasih kepada Universitas Mataram melalui Lembaga Penelitian dan Pengabdian kepada Masyarakat (LPPM) yang telah membiayai kegiatan pengabdian ini. Selain itu, ucapan terima kasih juga disampaikan kepada guru-guru SMA Negeri 1 Betukeliang yang menjadi peserta dalam kegiatan ini.

\section{Daftar Pustaka}

Albrecht, W. S., \& Sack, R. L. (2000). Accounting education: Charting the course through a perilous future. Accounting Education Series No. 16. Sarasota, FL: American Accounting Association.

Ariyati, E. 2010. Pembelajaran berbasis praktikum untuk meningkatkan kemampuan berpikir kritis mahasiswa. Jurnal Matematika dan IPA. 1 (2).

Bailin, S. (2002). Critical thinking and science education. Science and Education. 11: 361375.
PISA. (2015). PISA Results: Excellence and equity in education. Acces from http://www.oecd.org/education/pisa-2015results-volume-i-9789264266490-en.htm

Prayogi, S., \& Muhali. (2016). Developement of Active-Based-Inquiry Learning Model to Increase Critical Thinking Skills of Students Teachers Candidate of Physics. Proceeding on International Conference on Elementary and Teacher Education (ICETE). 22-23 October 2016, LombokIndonesia. Pp: 47-56.

Thompson, Claudette. 2011. Critical thinking across the curriculum: process over output. International Journal of Humanities and Social Science Vol. 1 No. 9.

TIMSS. (2015). TIMSS 2015 and TIMSS Advanced 2015 International Results. Acces from http://timss2015.org/\#/?playlistId=0\&video $\underline{\mathrm{Id}=0}$ 